\title{
Non-contact Study of Surfaces Created Using the AWJ Technology
}

Tibor Krenický

Faculty of Manufacturing Technologies, Department of Manufacturing Processes Operation, Technical University of Košice, Bayerova 1, 08001 Prešov, Slovakia. E-mail: tibor.krenicky@tuke.sk

Spatial measurement and evaluation of the surface profile parameters provide valuable and useful information about the relationship between the geometric characteristics of the surface and its functional properties. Evaluating the structure of surface area may help to explain a variety of problems in manufacturing technologies as it allows detailed quantitative study of geometric and dimensional changes of the surface profiles. AWJ cutting still generates unrevealed questions regarding interactions of the cutting material with the work-piece. The article presents experimental study of surface of steel material after AWJ cutting with usage of optical method that was selected as universal method that overcomes some of the shortcomings of contact methods.

Keywords: abrasive water-jet cutting, profile parameters, roughness, non-contact measurement, striation

\section{Acknowledgement}

The research work was supported by the Project of the $S F$ of the $E U$, Operational Programme Research and Develo-pment, Measure 2.2 Transfer of knowledge and technology from research and development into practice, project: Research and development of intelligent nonconventional actuators based on artificial muscles. ITMS code: 26220220103, projects VEGA 1/0409/13 and KEGA 027 TUKE - 4/2014.

\section{References}

[1] CHEN, F.L., SIORES, E. (2003). The effect of cutting jet variation on surface striation formation in abrasive water jet cutting, Journal of Materials Processing Technology, 135, pp. 1-5.

[2] HLAVÁČ, L.M., HLAVÁČOVÁ, I.M., GEMBALOVÁ, L., KALIČINSKÝ, J., FABIAN, S., MĚŠŤÁNEK, J., KMEC, J., MÁDR, V. (2009). Experimental method for the investigation of the abrasive water jet cutting quality, Journal of Materials Processing Technology, 209, pp. 6190-6195.

[3] HLAVÁČ, L.M. (2009). Investigation of the abrasive water jet trajectory curvature inside the kerf, Journal of Materials Processing Technology, 209, pp. 4154-4161.

[4] AKKURT, A. (2009). Surface properties of the cut face obtained by different cutting methods from AISI 304 stainless steel materials, Indian Journal of Engineering and Materials Sciences, 16, pp. 373-384.

[5] JURKO, J., PANDA, A. (2012). Study of the Surface Material AISI 304 Usable for Actuator after the Process of Turning, Applied Mechanics and Materials, 229-231, pp. 415-418.

[6] LEGUTKO, S., KROLCZYK, G., KROLCZYK, J. (2014). Quality Evaluation of Surface Layer in Highly Accurate Manufacturing, Manufacturing Technology, 1, pp. 50-56.

[7] DAHIL, L., DAHIL, I., KARABULUT, A. (2014). The implementation of the high technology methods of cutting on St 50 alloyed steel and the examination of the effects of cutting operation at the surface of material, Metalurgija, 53, pp. 89-92.

[8] MONNO, M., RAVASIO, C. (2005). The effect of cutting head vibrations on the surfaces generated by waterjet cutting, International Journal of Machine Tools \& Manufacture, 45, pp. 355-363.

[9] KRENICKÝ, T. (2011). Implementation of Virtual Instrumentation for Machinery Monitoring, Scientific Papers: Operation and Diagnostics of Machines and Production Systems Operational States. Lüdenscheid, RAM - Verlag, pp. 5-8.

[10] HLOCH, S., FABIAN, S. (2006). Qualitative analysis of AWJ factors affecting the surface roughnes, Wissenschaftiche Beiträge, Heft, pp. 113-119.

[11] KASINA, M., VASILKO, K. (2012). Experimental Verification of the Relation between the Surface Roughness and the Type of Used Tool Coating, Manufacturing Technology, 12, pp. 27-30.

[12] JURKO, J., PANDA, A., DŽUPON, M., PANDOVÁ, I., GAJDOŠ, M. (2011). Deformation of material under the machined surface in the manufacture of drilling holes in austenitic stainless steel, Chemické listy, Material in Engineering Practice 2011, HF TU Košice, 105, pp. 600-602.

[13] FABIAN S., SALOKYOVÁ Š. (2012). Experimental verification of abrasive mass flow impact on the technological head acceleration amplitude and vibrations frequency in the production system with AWJ technology, Manufacturing Technology, 12, pp. 18-21. 